ACTA MYCOLOGICA

Vol. 41 (1): 29-40

2006
Dedicated to Professor Alina Skirgietto

on the occasion of her ninety fifth birthday

\title{
A confusing duo: Calocybe cerina and Callistosporium pinicola (Agaricales)
}

\author{
EEF ARNOLDS
}

Holthe 21, NL 9411 TN Beilen, eefarnolds@hetnet.nl

Arnolds E.: A confusing duo: Calocybe cerina and Callistosporium pinicola (Agaricales). Acta Mycol. 41 (1): 29 40, 2006.

The name Calocybe cerina has recently been applied for two different species of agarics. After studying collections from different European countries it is concluded that the true Calocybe cerina is very close to $C$. chrysenteron and best regarded as a variety. The new combination Calocybe chrysenteron var. cerina is proposed and a full description of that taxon is given. The majority of collections, identified as $C$. cerina, appear to belong to a fungus, provisionally described by Bon as Callistosporium luteoolivaceum fo. minor. It is described here as a new species: Callistosporium pinicola. Calocybe juncicola is another species that might be confused with the two species mentioned before and therefore a full description is provided. The status of the genera Rugosomyces and Calocybe is discussed. The new combinations Calocybe obscurata and Calocybe pudica are made.

Key words: Callistosporium, Calocybe, Rugosomyces

\section{INTRODUCTION}

In The Netherlands in recent years several collections were made of a fairly small, white-spored agaric with an orange-brown pileus and crowded, orange-yellow lamellae, growing on stumps of coniferous trees. It was initially identified as Calocybe cerina (Pers.: Fr.) Donk (Arnolds, Becker 1993). An important indication was the presence of granules in the basidia that were apparently siderophilous, staining dark violet in acetocarmine with addition of iron. However, some characters were deviating from most descriptions in literature, in particular the striking red to violet staining of all tissues in $\mathrm{KOH}$ and ammonia, the complete absence of clamp-connections and the lignicolous habitat, suggesting that it could be an undescribed taxon.

Recently I came across descriptions of Callistosporium luteoolivaceum var. minor M. Bon ined. (Ludwig 2001; Wilhelm 2003) that showed striking resemblance with our material, e.g. the red staining in ammonia and $\mathrm{KOH}$. In this paper I shall try to unravel the identity of the collected material and I will discuss the taxonomic position of Calocybe cerina (Pers.: Fr.) Donk and the related C. juncicola (Heim) Sing. 


\section{WHAT IS CALOCYBE CERINA?}

Agaricus cerinus was initially described by Persoon (1801: 321) as a fairly small agaric, growing in pine forests (substrate not explicitly mentioned) with dark waxyellow ('flavo-cerinus opacus'), fleshy, flattened to depressed pileus; crowded, narrow lamellae and a taste becoming bitter after a while. In his sanctioning description Fries (1821:89) mainly copied Persoon's description, adding that the context and spore print are white. Most authors have interpreted the name as a species close to or identical with Calocybe chrysenteron (Bull.: Fr.) Sing. Pe rsoon (1801) treated Agaricus chrysenterus Bull. immediately after his $A$. cerinus. The two taxa are microscopically characterized by e.g very small, ellipsoid spores, a pileipellis in the form of a cutis with transitions to a trichodermium, and presence of clamp-connections.

A different interpretation of Agaricus cerinus was published by Arnolds \& Becker (1993) and accepted by e.g. Kala me es $(1995,2004)$. The basidiocarps of that fungus occur on dead wood, are slightly smaller and thin-fleshed, their tissues turn reddish in alkaline solutions and clamp-connections are absent.

After comparing collections and modern descriptions of these taxa I believe that the first-mentioned interpretation is in better agreement with the original diagnosis, mainly in view of the larger size of the basidiocarps, the thicker context and the substrate on soil and litter. Therefore I present first a description of this little-known fungus.

Calocybe chrysenteron (Bull.:Fr.) Sing. var. cerina (Pers.: Fr.) Arnolds nov. comb. - Fig. 1.

Basionym: Agaricus cerinus Pers.: Fr., Syst. mycol. 1: 89. 1821.

Agaricus cerinus Pers., Syn. meth. Fung.: 321. 1801; Agaricus cerinus Pers.: Fr., Syst. mycol. 1: 89. 1821; Tricholoma cerinum (Pers.:Fr.) Quél., Champ. Jura Vosges 1; 81. 187; Tricholoma chrysenteron subsp. cerinum (Pers.: Fr.) Konr. \& M., Icon. sel. Fung. 3: pl. 267, fig. 2. 1937; Calocybe cerina (Pers.: Fr.) Donk in Beih. Nova Hedwigia 5: 43. 1962; Rugosomyces cerinus M. Bon in Doc. mycol. 21 (82): 66. 1991. - Tricholoma pseudoflammula J. Lange in Dansk bot. Ark. 8(3): 24. 1933; Spec. Pl.: 1173. 1753; Calocybe pseudoflammula (J. Lange) Sing. in Sydowia 15: 47. ('1961') 1962; Rugosomyces pseudoflammula (J. Lange) M. Bon in Doc. mycol. 21(82): 65. 1991.

Excl. - Calocybe cerina sensu Arnolds \& Becker in Coolia 36: 70-73, fig. 1.1993 ( Callistosporium pinicola); sensu Dermek in Fung. rar. Ic. col. 17: 10.1987 ( C. fallax); sensu Kalamees in Scripta mycol. 18: 84. 2004 ( Callistosporium pinicola); Rugosomyces pseudoflammula sensu M. Bon, Fl. Mycol. Eur. 5, Collybio-Marasmïö̈des: 110.1999 ( C. chrysenteron).

Sel. icon. - Cetto, Funghi Vero 3: pl. 1024. 1979; Flora Batava 25 : pl. 1994a. 1920; Konr. \& M., Icon. sel. Fung. 3: pl. 267, fig. 2. 1927; J. Lange, Fl. Agar. Dan. 1: pl. 24B. 1935 (as T. pseudoflammula); Schweizer Pilzt. 5: pl. 42. 1972.

Sel. descr. \& figs. - M. Bon, Fl. Mycol. Eur. 5, Collybio-Marasmïoïdes: 111. 1999; Konr. \& M., Icon. sel. Fung. 3: pl. 267 II. 1927; J. Lange, Fl. Agar. Dan. 1: 57.1935 (as T. pseudoflammula).

Pileus 12-40(-50) mm, convex at first, with thin, involute margin, then planoconvex to flattened or slightly depressed with straight, often undulating margin, with or without weak umbo, not hygrophanous, brownish yellow, brownish orange to orange-brown from the beginning (e.g. K. \& W. 5B7, 5C8, 6C7, 6C8), dull and dry, 


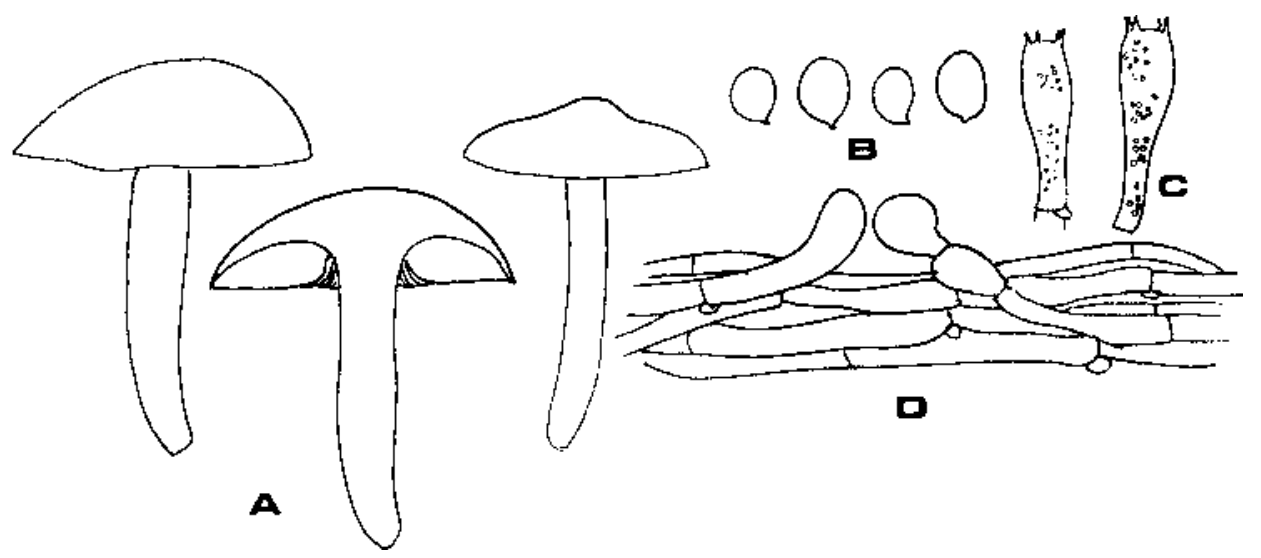

Fig. 1. Calocybe chrysenteron var. cerina. A. Basidiocarps x 1; B. Spores x 2000; C. Basidia x 1000; D. Pileipellis x 1000 (all from Arnolds 05 87).

smooth to slightly tomentose, especially at centre, not striate. Lamellae, L 38-60, 1 1-7, adnexed, emarginate to adnate, very crowded, segmentiform, up to $5 \mathrm{~mm}$ broad, thin, lemon- to golden-yellow or orangeish yellow, with concolorous, entire edge. Stipe $20-50 \times 2-6(-10) \mathrm{mm}$, cylindrical or compressed, often tapering to base, stuffed to fistulose, concolorous with pileus, sometimes weakly yellow striate lengthwise, at apex pruinose, at base white tomentose or strigose-hairy. Context whitish, pale yellow to lemon-yellow. Smell farinaceous when cut; taste first farinaceous, then often more or less bitter. Spore print white.

Spores 2.5-4.0(-4.5) x 2.0-3.0 $\mu \mathrm{m}$, av. 3.1-3.5 x 2.3-2.5 $\mu \mathrm{m}, \mathrm{Q} \quad$ 1.2-1.5, Qav. 1.31.4, broadly ellipsoid to ellipsoid. Basidia 17-23 x 4.0-7.0 $\mu \mathrm{m}$, clavate, 4-spored, with numerous small granules. Lamella edge fertile. Hymenophoral trama subregular, made up of hyphae with cylindrical or slightly inflated elements, $3.0-12 \mu \mathrm{m}$ broad. Pileipellis a cutis of repent hyphae, 2.0-6.0 $\mu \mathrm{m}$ broad, often with some broader, ellipsoid to subglobose cells, often at centre with trichodermial tufts of erect and ascending hyphae, with yellowish intracellular pigment. Stipitipellis a cutis, made up of repent hyphae, 2.0-4.0 $\mu \mathrm{m}$ wide, at stipe apex with clusters of undifferentiated, erect hyphal tips up to $40 \mu \mathrm{m}$ long, 2.0-5.0 $\mu \mathrm{m}$ wide. Clamp-connections present.

Chemical reactions: No part of basidiocarp reddening with $\mathrm{KOH}$ or ammonia. Granules in basidia staining dark purple in acetocarmine with iron (siderophilous).

Habitat and distribution: Mainly on needle litter in coniferous forests (Picea, Abies), also reported under broad-leaved-trees (Quercus); on mesic to dry, calcareous soil. Probably widespread in Europe but much rarer than var. chrysenteron. Exact distribution unknown in view of taxonomic confusion (see notes). With certainty recorded from Denmark, Germany, Switzerland (Kon rad \& Maublanc 1937) and The Netherlands (Flora Batava, 1920).

Collections examined. - DENMARK: Rubjerg, Knude Plantage, 26 Sept. 1990, J. Vesterholt 90-505 (C); Same loc., 21 Oct. 1991, J. Vesterholt 91-801 (C) - GERMANY: Bavaria, Frankische Schweiz, Ebermannstadt, Aufsesstal, 19 Sept. 2005, E. Arnolds 05-87 (L). 
The studied collections differ from typical Calocybe chrysenteron morphologically only in the duller, more brownish colours of pileus and stipe and the paler context. In var. chrysenteron all parts of the basidiocarps are bright yellow to orange-yellow (e.g. Ludwig 2000). In addition var. cerina seems to be almost confined to coniferous forests, whereas var. chrysenteron is mostly (but not always) found in deciduous forests. Both taxa are calciphilous. Some modern authors synonymize $C$. chrysenteron and C. cerina (e.g. Ludwig 2001), others treat them as separate species (e.g. Bon 1999; Hor ak 2005). The differences are small but seem to be rather constant and warrant in my opinion a distinction in the rank of variety.

Many modern authors regard Tricholoma pseudoflammula J. Lange as a synonym of Calocybe chrysenteron (e.g. Ludwig 2001; Kalamees 2004), but Lange's plate (24B) is typical of var. cerina in view of the orange-brown pileus, already in young basidiocarps, and the pale context.

For differences with C. cerina sensu Arnolds and Becker ( Callistosporium pinicola) see notes on that species.

\section{A DOUBLE OF CALOCYBE CERINA: CALLISTOSPORIUM PINICOLA}

Callistosporium pinicola Arnolds nov. spec. - Fig. 2.

Pileus (5-)10-30 mm convexus margine involutus, dein planiusculus vel depressus, haud vel leviter hygrophanus, flavo-brunneus, aurantio-brunneus, rufo-brunneus, numquam striatus, siccus, centro tomentosus. Lamellae adnatae vel emarginatae, confertae, tenuae, flavae vel aurantio-flavae. Stipes (12-)14-32 x (1,5-)2-3,5 mm, cylindricus vel compressus, pileo subconcolorus. Caro tenuis, fragilis, pallide flava. Odor nullus vel farinaceus. Sapor nullus vel amarescens.
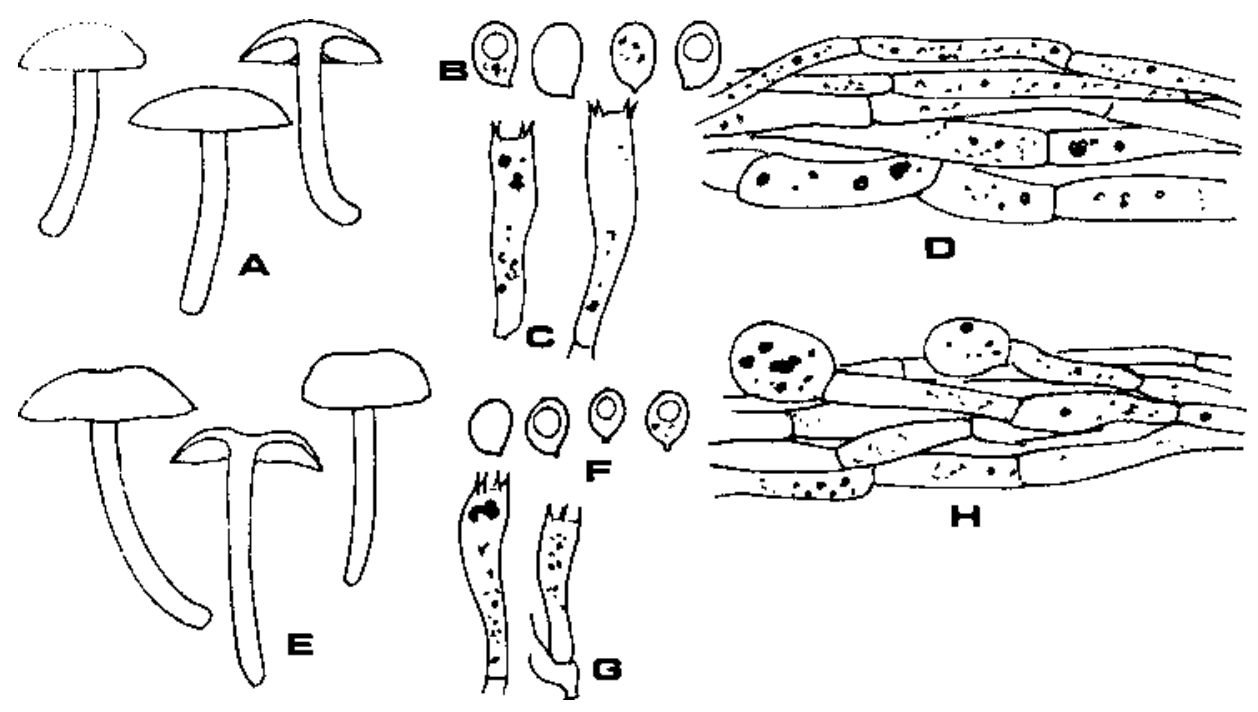

Fig. 2. Callistosporium pinicola. A, E. Basidiocarps x 1; B, F. Spores x 2000; C, G. Basidia x 1000; D, H. Pileipellis x 1000 (A D from Arnolds 6100 (holotype), E H form A. Becker, 6 Oct. 1990). 
Sporae (2,5-)2,8-4,7 x 2,0-3,5 $\mu \mathrm{m}$, ellipsoideae vel late ellipsoideae, laeves, hyalinae, saepe corpusculis xanthis vel brunneis. Basidia 12-25 x 3,5-6,0 $\mu \mathrm{m}$, clavatae, tetraspora. Lamellarum trama regularis. Cystidia nulla. Pileipellis cutis vel trichodermium, hyphis 2,0-5,5 $\mu \mathrm{m}$ latis, interdum ex cellulis inflatae ad 8,0 $\mu \mathrm{m}$. Fibulae absentes. Basidia, trama et pileipellis granulis numerosis brunneis in aqua, rubescentis vel violascentis in $\mathrm{KOH}$ et ammonia.

Habitatio ad truncos putridos coniferarum. Aestate- automno.

Holotypus: 'The Netherlands, Dwingeloo, Lheederzand, 4 Oct. 1990, E. Arnolds 6100' (L).

Synon.: Callistosporium xanthophyllum (Malenc. \& Bert) M. Bon fo. minor M. Bon ad int., in Flore mycol. Europe 2: 83.1991 (invalid, without latin diagnosis and without designation of type).

Misapplied names: Calocybe cerina sensu Arnolds \& Becker in Coolia 36: 70. 1993; sensu Kalamees in Scripta mycol. 18: 84. 2004.

Sel. plates. - Ludwig, Pilzkompendium 1: pl. 15, fig. 6.2 A, C. 2000 (as Callistosporium luteoolivaceum var. minor M. Bon ined.); Wilhelm in Schweiz. Z. Pilzk. 81: 64. 2003 (as Callistosporium luteoolivaceum var. minor M. Bon).

Sel. descr. \& figs. - Arnolds \& Becker in Coolia 36: 70-73, fig. 1. 1993 (as Calocybe cerina); Ludwig, Pilzkompendium 1: 37-38. 2001 (as Callistosporium luteoolivaceum var. minor M. Bon ined.); Wilhelm in Schweiz. Z. Pilzk. 81: 62-66. 2003 (as Callistosporium luteoolivaceum var. minor M. Bon) .

Pileus (5-)10-30 mm, first convex with narrow, involute margin, then plano-convex to flattened with straight margin, often with slightly depressed centre, not or weakly hygrophanous, usually vividly yellow-brown, orange-brown, rusty-brown to red-brown, occasionally with olivaceous hue near centre (e.g. K. \& W. 5D7, 6D7, 7E7; Mu. 5 YR 6/6, 10 YR 4/6, 5/8), rarely entirely butter-yellow (K. \& W. 4A5), not striate, dry, smooth or slightly radially fibrillose, often at centre tomentose. Lamellae, L 28-36, 1 (1-)3-7, adnate to strongly emarginate, crowded to very crowded, segmentiform, up to $4 \mathrm{~mm}$ broad, thin, butter-yellow, golden-yellow to yellowish orange (Mu. 2.5 Y 6/8; K. \& W. 4A5, 5C6, 4C6), with concolorous, entire edge, becoming dark red-brown to almost black in exsiccata. Stipe (12-)14-32 x (1.5-)2-3.5 mm, cylindrical or sometimes compressed, solid or narrowly fistulose, concolorous with pileus or paler yellow-brown, slightly aerenchymatic at first, then smooth or white striate lengthwise, at apex slightly pruinose, at base often white tomentose. Context in pileus thin, up to $2 \mathrm{~mm}$ thick, fragile, concolorous with surface, inside stipe pale yellow. Smell almost absent or weakly farinaceous; taste mild to slightly bitter. Spore print pale cream-coloured.

Spores (2.5-)2.8-4.5 x 2.0-3.5 $\mu \mathrm{m}$, av. 3.0-4.2 x 2.3-3.4 $\mu \mathrm{m}, \mathrm{Q} \quad 1.1-1.5(-1.8)$, Qav. 1.2-1.4, in majority broadly ellipsoid or ellipsoid, some subglobose or oblong, smooth, not amyloid, in water colourless or with yellow, refractive body, in part also with brown granules ('necropigment'), staining reddish in ammonia and $\mathrm{KOH}$, dark red to violet-brown in congored and acetocarmine. Basidia 12-25 x 3.5-6.0 $\mu \mathrm{m}$, clavate, 4-spored, in water with numerous brown granules and larger clots, staining like spores. Lamella edge fertile. Hymenophoral trama subregular, made up of rather narrow hyphae with cylindrical or slightly inflated elements, 13-90 x 3.0-14 $\mu \mathrm{m}$, with numerous brown granules and clots. Pileipellis mainly a poorly differentiated cutis, made up of repent, interwoven hyphae, 2.0-5.5 $\mu \mathrm{m}$ broad, with yellow intracellu- 
lar pigment, towards the centre often with trichodermial fascicles of ascending and erect hyphae, often with ellipsoid to subglobose terminal cells up to $8.0 \mu \mathrm{m}$ wide, with brown granules and clots. Stipitipellis a cutis, made up of repent hyphae, 2.0-4.0 $\mu \mathrm{m}$ wide. Clamp-connections absent.

Chemical reactions: all parts of the fresh basidiocarp turning immediately dark red-brown to violet-brown with $\mathrm{KOH} \mathrm{5 \%}$ and $10 \%$ ammonia (macroscopically); preparations of all tissues turning immediately violet in $\mathrm{KOH} 5 \%$ and reddish in $10 \%$ ammonia, also staining surrounding liquid; granules and clots becoming vinaceous red or dark violet. Granules staining dark purple in acetocarmine with iron (seemingly siderophilous).

Habitat and distribution: Saprotrophic, solitary or in small groups, on strongly decayed stumps or dead trunks of coniferous trees, mainly recorded from Pinus sylvestris, also on Pinus pinea and Picea abies, in coniferous and mixed stands, mainly on acidic, sandy and loamy soils. July-Nov. Apparently widespread but rare in CentralEurope; recorded from The Netherlands, southern and eastern Germany (Lu dwig 2001; Wilhelm 2003), Switzerland (Kalamees 2004, as C. cerina), Austria (Kala mees 2004, as C. cerina), France (Wilhelm 2003; Bon 1995) and Italy.

Collections examined. AUSTRIA: Steiermark, Gleichenberg, Trautmannsdorf, 21 Aug. 2003, W. Wofar \& A. Hausknecht (WU, as Calocybe cerina). - FRANCE: Elsass, Hardt, 16 Sept. 1998, M. Wilhelm 596 (herb. Wilhelm); Sondersdorf, 31 July 2000, M. Wilhelm 709 (herb. Wilhelm); Oltingue, 27 Aug. 2002, M. Wilhelm 793 (herb. Wilhelm). - ITALY: Tuscany, Orbetello, Bosco di Patanella, 27 Oct. 1987, Th. W. Kuyper 2804 (L, as Calocybe cerina). - THE NETHERLANDS: Dwingeloo, Lheederzand, 4 Oct. 1990, E. Arnolds 6100 (L, as Calocybe cerina); Smilde, Hardersbosch, 13 Nov. 1991, E. Arnolds 6232 (L, as Calocybe cerina); Diever, State Forest Smilde, 3 Nov. 1986, B. de Vries 5193 (L, as Calocybe spec.); Diever, State Forest Smilde, 31 Aug. 1992, J. Baar 92/11 (L, as Calocybe chrysenteron); Ede, estate Roekel, 21 Sept. 2002, P.J. Keizer s.n. (L, as Calocybe cerina); Bergen-Schoorl, State Forest, A.G. Becker, 6 Oct. 1990 (L, as Calocybe cerina).

Callistosporium pinicola does not belong to the genus Calocybe in view of the presence of small granules and larger clots of brown necropigment in the basidia, spores trama and pileipellis, as well as by the complete absence of clamp-connections. However, the necropigment can only be recognized as such in preparations in water (also of exsiccata), because it is immediately turning red to violet in ammonia and $\mathrm{KOH}$. Since exsiccata are usually revived in these solutions the brown pigment is easily overlooked in dried specimens. Moreover the necropigment is strongly staining purple with acetocarmine, thus mimicking the siderophilous granules of Calocybe species. Therefore it is not surprising that the majority of herbarium collections, identified as Calocybe cerina, appears to belong to Callistosporium pinicola. In this context it is interesting to note that Maire (1937) described Callistosporium luteoolivaceum under the name Tricholoma chrysenteron ( Calocybe chrysenteron) var. olivascens Maire (Redhead 1982). Apparently confusion between the two genera has occurred before.

The presence of necropigment, the red staining of tissues in $\mathrm{KOH}$ and ammonia and the absence of clamp-connections are all characters of the genus Callistosporium Sing. The present species belongs to subgenus Callistosporium in view of the crowded lamellae, small, ellipsoid spores, short basidia and the pigment not turning blue 
in ammonia (Bon, 1991). Taxonomy and nomenclature of this group are still rather controversial. Bon (1991) distinguished two species, C. xanthophyllum (Malenc. \& Bert.) M. Bon and C. elaeodes (Romagn. ex) M. Bon, but Redhead (1982) and Noordeloos (1995) united these taxa in one species and synonymised it with the North-American C. luteoolivaceum (Berk. \& Curtis) Sing, which name has priority in that case. Ludwig (2001) described $C$. foetens E. Ludwig as additional new species in this subgenus, characterized by a strong unpleasant smell.

Callistosporium pinicola differs from all species mentioned above in the first place by the very small spores. Ludwig (2001) described the spores of C. luteoolivaceum as 5-5.5(-6.5) x 3.5-4 $\mu \mathrm{m}$ and Bon (1991, as C. xanthophyllum) as (5.0-)5.5-6.5(-7) $\mathrm{x}(3-) 4-4.5(-5) \mu \mathrm{m}$. Spores in the type collection of $C$. elaeodes measured $6.5-7.5 \mathrm{x}$ 3.5-4.4(-5.0) $\mu \mathrm{m}$ (Bon 1976). In addition it is striking that the basidiocarps of $C$. pinicola are generally lacking green colours, so characteristic for other species of Callistosporium. Only in one of the studied collections a weak olivaceous tone was observed in the centre of the pileus. The habitat on stumps and trunks of coniferous trees is also characteristic for $C$. pinicola. Other species are usually growing on deciduous wood or litter. In view of these characteristics the identity of the collection, depicted by Ludwig (2000) in Pl. 6.2 B as C. luteoolivaceum var. minor, is in my opinion doubtful since the pileus is distinctly green and the spores are described as larger: 4-5 x 3-4 $\mu \mathrm{m}$.

In the field Callistosporium pinicola may also be mistaken for a species of Simocybe or Gymnopilus.

\section{THE TAXONOMIC POSITION OF CALOCYBE JUNCICOLA}

Next to Calocybe cerina sensu Arnolds \& Becker, there is a second European species of Calocybe in which red staining of tissues in alkaline solutions has been reported, viz. Calocybe juncicola (R. Heim) Sing. (Mo r e no 1995). Since this reaction is considered a characteristic feature of the genus Callistosporium, I have examined two collections of that species in order to re-evaluate its taxonomic position.

Calocybe juncicola (R. Heim) Sing. in Sydowia 15: 47. ('1961') 1962. - Fig. 3.

Tricholoma chrysenteron var. juncicola R. Heim in Treb. Mus. Cienc. nat. Barcelona 15: 101. 1934; Calocybe chrysenteron var. juncicola (R. Heim) G. Moreno in Cryptog. Mycol. 15: 240. 1995; Rugosomyces chrysenteron var. juncicolus (R. Heim) M. Bon in Doc. Mycol. 21 (82): 65. 1991.

Sel. icon. - Cetto, Funghi Vero 6: pl. 2414. 1989; Ludwig, Pilzkompendium 1: pl. 19, fig. 7.9. 2000.

Sel. descr. \& figs. - Hauskn. \& Zuccherelli in Boll. Gruppo micol. G. Bres. 1994: 68-69, fig. 1 a-c. 1994; Ludwig, Pilzkompendium 1: 48. 2000; G. Moreno in Cryptog. Mycol. 15: 240-241, Fig. 1. 1995.

Pileus 10-30 mm, truncate campanulate to hemispherical at first, then convex to flattened, with or without umbo, often irregular, not hygrophanous, not striate, bright orange to golden yellow or brownish orange (e.g. K. \& W. 4A8, 6A6, 6A7, 6B8), uniformly coloured or with slightly paler margin, slightly aerenchymatic in places when young, glabrous and dry. Lamellae, L 30-40, 1 3-7, emarginate to adnexed, moderately crowded to crowded, segmentiform, up to $4 \mathrm{~mm}$ broad, thin, vividly yellow, butter-yellow or ochre-yellow (K. \& W. 4A5/6, 4B6), with concolor- 

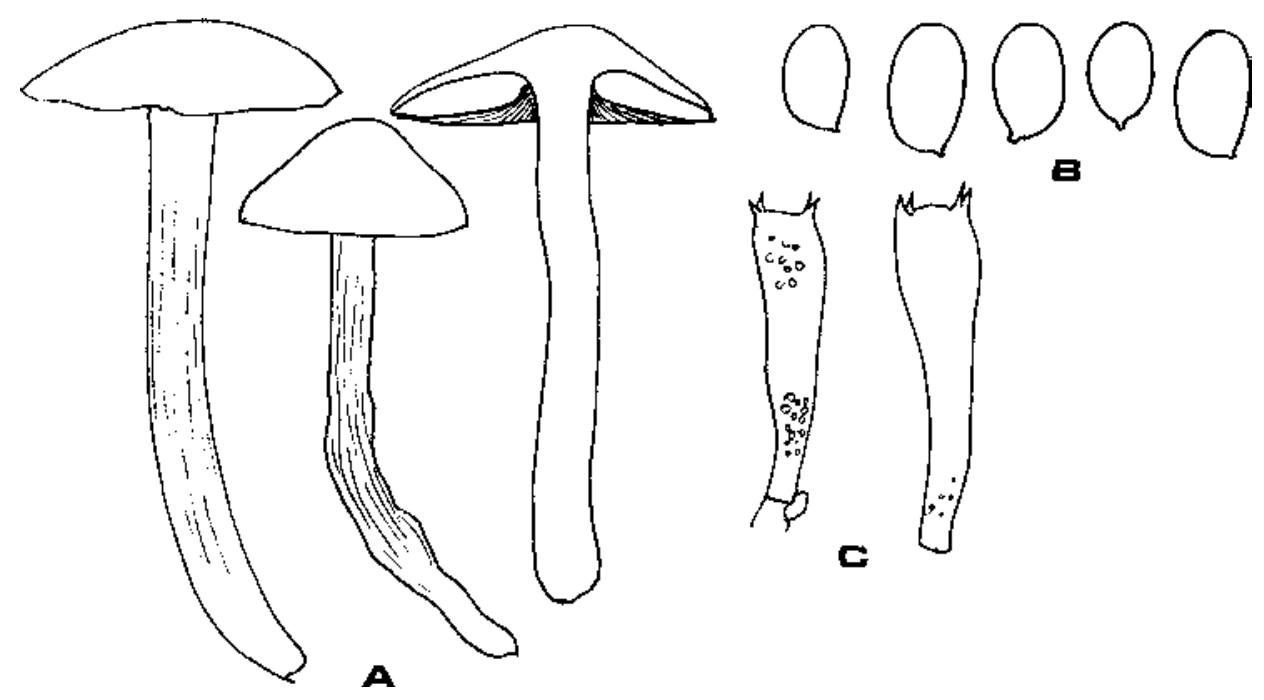

Fig. 3. Calocybe juncicola. A. Basidiocarps x 1; B. Spores x 2000; C. Basidia x 1000 (all from Noordeloos 20266).

ous, entire or eroded edge. Stipe 30-60 × 2-10 mm, subcylindrical or tapering towards base, often compressed or twisted, often slightly broader towards apex or base, solid, paler than the pileus, pale yellow, butter-yellow to brownish yellow (e.g. K. \& W. 4A4, 5, 6, 4B6), fibrillose striate lengthwise, appearing pruinose by aerenchymatic tissue. Context in pileus up to $4 \mathrm{~mm}$ thick, pale yellow. Smell and taste strongly farinaceous, taste slightly adstringent. Spore print unknown.

Spores (3.5-)4.5-6.5 x (2.5-)3.0-3.7(-4.0) $\mu \mathrm{m}$, av. 5.0-5.4 x 3.2-3.3 $\mu \mathrm{m}, \mathrm{Q} \quad$ 1.3-1.9, Qav. 1.5-1.65, ellipsoid or ellipsoid-oblong, smooth, not amyloid, in water and ammonia colourless. Basidia 25-36 x 5.0-8.0 $\mu \mathrm{m}$, clavate, 4-spored or a few 2-spored, in part with few to fairly numerous small granules. Lamella edge fertile, but sometimes with scattered cylindrical basidiola, 18-23 x 4.0-5.0 $\mu \mathrm{m}$. Pleurocystidia absent. Hymenophoral trama subregular, made up of rather narrow hyphae with cylindrical or slightly inflated elements, $2.0-14 \mu \mathrm{m}$ broad. Pileipellis a poorly differentiated cutis, made up of repent, interwoven hyphae, 1.5-5.0 $\mu \mathrm{m}$ broad, in places with ascending to erect hyphae, with pale yellow intracellular pigment. Stipitipellis a cutis, made up of repent hyphae, 2.0-4.0 $\mu \mathrm{m}$ wide. Clamp-connections abundant in hymenium and trama.

Chemical reactions: Preparations of all tissues turning immediately reddish to violet in $\mathrm{KOH} \mathrm{5 \%}$ and ammonia 10\%; macroscopic reactions on fresh basidiocarps unknown. Granules in basidia staining dark purple in acetocarmine with iron (siderophilous).

Habitat and distribution: Saprotrophic, usually fasciculate, on roots and litter in dense tussocks of Juncus spp. (e.g. Juncus maritimus, Juncus acutus) in open forests and dune slacks. Nov. Apparently very rare in southern Europe, known from Italy and Spain. 
Collections examined. - ITALY: Ravenna, Pineta San Vitale, Bardello, 6 Nov. 2000, A. Hausknecht et al. (WU no. 20752); same dat. and loc., M.E. Noordeloos 20266 (L).

The reddish staining of tissues in alkaline solutions was only reported by Mo r e no et al. (1995), who mentioned a violet discoloration of the solution when making a preparation of the lamellae in $\mathrm{KOH}$. The reaction was not mentioned in other descriptions (Hausknecht, Zuccherelli 1994; Cetto 1989; Ludwig 2001) or in the descriptive notes accompanying the collections. The reddening in ammonia and $\mathrm{KOH}$ is very similar to that of Callistosporium pinicola, although slightly weaker. Nevertheless, Calocybe juncicola seems not to be related to the latter species in view of the absence of brown necropigment, the abundance of clamp-connections and the presence of truly siderophilous granules in the basidia, although these granules seem to be less numerous and striking than in other Calocybe species. Otherwise, C. juncicola differs from $C$. chrysenteron (incl. var. cerina) mainly in duller colours, striate stipe, larger and more elongate spores and specific habitat.

A second European species of Calocybe with violaceous red discoloration of tissues in $\mathrm{KOH}$ is Rugososmyces pudicus $\mathrm{M}$. Bon \& Contu, collected in moist forest of Populus on Sardegna (Contu, Bon 2000). It has small basidiocarps with a pinkish brown to yellow-brown pileus up to $20 \mathrm{~mm}$, differing mainly from $C$ juncicola in immediate reddening of the context on exposure to the air and broader spores (5.0-6.0 $\mathrm{x} 3.5-4.5 \mu \mathrm{m})$ that are slightly rugulose, as was also demonstrated with SEM microscopy (Contu, Ortega 2001).

\section{CALOCYBE OR RUGOSOMYCES?}

The genus Calocybe was erected (but invalidly published) by Kühner (1938) in order to accommodate tricholomoid, white-spored agarics with basidia containing siderophilous granules in combination with vividly coloured basidiocarps. Donk (1962) validated this name and selected Calocybe georgii (L.) Kühner ( C. gambosa (Fr.: Fr.) Donk) as type species. Several authors have discussed the possible heterogeneity of this genus since. Kal a mees (1992) has proposed the genus Tricholomella for Calocybe constricta (Fr.: Fr.) Sing., deviating from other species in presence of a partial veil, verrucose spores, large basidia and ecological preference for substrates with high ammonia content. This distinction was later confirmed by phylogenetic studies using molecular characters (Hoffstetter et al. 2002; Moncalvo et al. 2002).

The genus Gerhardtia was created by Bon (1994) for Calocybe borealis A. Riva ( Lyophyllum incarnatobrunneum Ew. Gerhardt), a species deviating in minutely verruculose spores and absence of clamp-connections. Since verruculose spores have also been observed in Rugosomyces (Calocybe) pudicus (Contu and Orte ga 2001), the status of this genus seems questionable. The phylogenetic relationships with the rest of Calocybe (and Lyophyllum) has not yet been studied.

Earlier Raithelhuber (1979) erected the genus Rugosomyces for the two species of Calocybe with a cellular pileipellis (hymeniderm) instead of a pileipellis of slender hyphae (cutis): the type species Rugosomyces onychinus (Fr.) Raithelh. and $R$. fallax (Sacc.) M. Bon. This concept was adopted by e.g. Hor ak (2005), but Bon (1991) extended Rugosomyces to all small species with collybioid habit, a pileipellis 
with more or less free ending hyphal tips, often with inflated cells, and mixed parietal and intracellular pigments. Calocybe was restricted by Bon (1.c.) to a few large, tricholomoid species with intracellular pigments. This concept was accepted by e.g. Kalamees (2004). However, molecular studies of the Lyophylleae have demonstrated that Calocybe (with the exception of $C$. constricta, possibly also $C$. borealis; see above) forms a single clade and is probably of monophyletic origin (Hoffstetter et al. 2002; Moncalvo et al. 2002). Therefore there seems to be no good reason to recognise Rugosomyces as a separate genus.

In this connection I propose two new combinations:

Calocybe pudica (M. Bon \& Contu) Arnolds comb. nov.

Basionym: Rugososmyces pudicus M. Bon \& Contu in Doc. Mycol. 29 (116): 35. 2000.

Calocybe obscurata (P. Karst.) Arnolds comb. nov.

Basionym: Tricholoma cerinum Pers. ssp. obscuratus P. Karst. in Meddeland. Soc. Fauna Fl. Fenn. 5: 43.1879.

\section{CALLISTOSPORIUM AND CALOCYBE}

The genus Callistosporium is assigned to the Tricholomatoideae and not to the Lyophylloideae in view of the absence of siderophilous granules in the basidia. Also in phylogenetic analysis the genera seem not to be closely related to each other (Moncalvo et al. 2002). However, it might be interesting to study the relationships between these groups more closely in view of the remarkable convergence between some species. Also the chemical composition of the necropigment in Callistosporium deserves attention.

Acknowledgements. This paper is dedicated with great pleasure to Professor Alina Skirgiełło, a living monument of vitality and a source of inspiration for all of us!

Thanks are due to Anton Hausknecht (Maissau, Austria), Markus Wilhelm (Allschwil, Switzerland) and the curators of the herbaria of the Botanical Museum in Copenhagen (C) and the National Herbarium in Leiden (L) for sending me valuable collections on loan. I am also indebted to Thomas Kuyper (Wagenin gen, The Netherlands) for some critical remarks on the manuscript of this paper.

\section{REFERENCES}

Arnolds E., Becker A. 1993. Over Calocybe cerina en enkele verwanten. Coolia 36: 6978.

B on M. 1976. Le genre Callistosporium Singer. Doc. mycol. 6 (22/23): 279286.

Bon M. 1991. Les genres Echinoderma (Locq. ex Bon) st. nov. et Rugososmyces Raithelhuber ss. lato. Doc. mycol. 21 (82): 6166.

Bon M. 1991. Flore mycologique d' Europe 2. Tricholomataceae 1. Doc. mycol., Mém. hors Sér. 2: 1149.

Bon M. 1994. Deux Lyophylloideae interessantes et le genre Gerhardtia st. et nom. nov. Doc. mycol. 24(93): 6568.

B on M. 1999. Flore mycologique d'Europe 5. Les Collybio Marasmïoïdes et ressemblants. Doc. mycol., Mém. hors Sér. 5: 1171.

Cet to B. 1989. Funghi Vero 6. Trento.

Contu M., Bon M. 2000. Une nouvelle espèce de Rugosomyces 'rougissant'. Doc. Mycol. 29(116) : 3536.

Contu M., Ortega A. 2001. Studi sulle Lyophyllaceae della Sardegna.V. Morfologia sporale di $R u$ gososmyces pudicus Bon \& Contu ed implicazioni sulla sua posizione sistematica. Bol. Soc. micol. Madrid 26:173 176 . 
Donk M.A. 1962. The generic names proposed for Agaricaceae. Beih. Nova Hedwigia 5 : 1320.

Fries E.M. 1821. Systema mycologicum 1. Gryphiswaldiae.

Hausknecht A., Zuccherelli A. 1994. Ritrovamenti interessanti dal Ravennate. 3e Parte. Boll. Gruppo micol. G. Bresadola 1994: 6795.

Hofstetter V., Clémencon H., Vilgalys R., Moncalvo J M. 2002. Phylogenetic analyses of the Lyophylleae (Agaricales, Basidiomycota) based on nuclear and mitochondrial rDNA sequences. Mycol. Res. 106: 10431059.

Hor a k E. 2005. Röhrlinge und Blätterpilze in Europa. Elsevier, München.

Kala mees K. 1992. Tricholomella, a new genus, with the distribution data of Tricholomella constrictum comb. nov. in East Europe and Asia. Persoonia 14: 445447.

Kal a mees K. 1995. On Rugosomyces fallax and allied species (Tricholomatales). Doc. Mycol. 25 (98 100): 229236.

Kalamees K. 2004. Palearctic Lyophyllaceae (Tricholomatales) in northern and eastern Europe and Asia. Scripta Mycologica 18. Tartu.

Kon rad P., Maublanc A. 1927. Icones selectae Fungorum 3. Paris.

Kühner R. 1938. Utilisation du carmin acétique dans la classification des agarics leucosporés. Bull. mens. Soc. Linn. Lyon 7: 204212.

Lange J.E. 1935. Flora Agaricina Danica 1. Copenhagen.

Ludwig E. 2000. Pilzkompendium 1, Abbildungen. IHW Verlag, Eching.

Ludwig E. 2001. Pilzkompendium 1, Beschreibungen. IHW Verlag, Eching.

Maire R. 1937. Fungi Catalaunici. Contribution à l' étude de la Flore Mycologique de la Catalogne. Publ. Inst. bot. Barcelona 3 (4): 1128.

Moncalvo J M,Vilgalys R., Redhead S.A., Johnson J.E., James T.Y., Aime M.C., Hofstetter V., Verduin S.J.W., Larsson E., Baroni T.J., Thorn R.G., Jacobs son S., Clémencon H., Miller Jr., O.K. 2002. One hundred and seventeen clades of euagar ics. Mol. Phylogenet. Evol. 23: 357400.

Moreno G., Arenal F., González V. 1995. Algunos Agaricales de Espana. Crypt. Mycol. 15: 239 254.

No or de lo os M.E. 1995. Callistosporium. In: Bas, C., Kuyper, Th.W., Noordeloos, M.E., Vellinga E.C. (eds). Flora agaricina neerlandica 3: 104. A.A. Balkema, Rotterdam, Brookfield.

Pers o on C.H. 1801. Synopsis methodica fungorum. Gottingae.

Raithelhuber J. 1979. Calocybe Kühner Ein Sammelgattung? Metrodiana 8: 910.

Red he ad S.A. 1982. The systematics of Callistosporium luteo olivaceum. Sydowia 35: 223235.

Wilhelm M. 2003. Callistosporium luteoolivaceum var. minor M. Bon, Kleinsporiger Scheinrübling. Schweiz. Z. Pilzk. 2003: 6266.

\section{Podwójna niejasność: Calocybe cerina i Callistosporium pinicola (Agaricales)}

\section{Streszczenie}

Nazwa Calocybe cerina była ostatnio stosowana dla dwóch różnych gatunków grzybów aga rikoidalnych. Na podstawie analizy materiałów z różnych krajów europejskich autor dochodzi do wniosku, że prawdziwie gatunek Calocybe cerina jest bardzo bliski C. chrysenteron i propo nuje nową kombinację Calocybe chrysenteron var. cerina podając opis nowego taksonu. Więk szość badanych kolekcji określonych jako C. cerina, okazała się taksonem, który Bon opisał prowizorycznie jako Callistosporium luteooliraceum fo. minor. W nieniejszym artykule został on opisany jako nowy gatunek: Callistosporium pinicola. Opis pozwala wyraźnie odróżnić inny gatunek Calocybe juncicola. Równocześnie dyskutowany jest status rodzajów Rugosomyces i Calocybe. Podane są też nowe kombinacje Calocybe obscurata i Calocybe pudica. 
